\title{
National Ignition Facility Cryogenic Target Systems Interim Management Plan
}

\author{
B. Warner
}

April 25, 2002

U.S. Department of Energy

Lawrence

Livermore

National

Laboratory 


\section{DISCLAIMER}

This document was prepared as an account of work sponsored by an agency of the United States Government. Neither the United States Government nor the University of California nor any of their employees, makes any warranty, express or implied, or assumes any legal liability or responsibility for the accuracy, completeness, or usefulness of any information, apparatus, product, or process disclosed, or represents that its use would not infringe privately owned rights. Reference herein to any specific commercial product, process, or service by trade name, trademark, manufacturer, or otherwise, does not necessarily constitute or imply its endorsement, recommendation, or favoring by the United States Government or the University of California. The views and opinions of authors expressed herein do not necessarily state or reflect those of the United States Government or the University of California, and shall not be used for advertising or product endorsement purposes.

This work was performed under the auspices of the U. S. Department of Energy by the University of California, Lawrence Livermore National Laboratory under Contract No. W-7405-Eng-48.

This report has been reproduced directly from the best available copy.

Available electronically at http://www.doe.gov/bridge

Available for a processing fee to U.S. Department of Energy

and its contractors in paper from

U.S. Department of Energy

Office of Scientific and Technical Information

P.O. Box 62

Oak Ridge, TN 37831-0062

Telephone: (865) 576-8401

Facsimile: (865) 576-5728

E-mail: reports@adonis.osti.gov

Available for the sale to the public from

U.S. Department of Commerce

National Technical Information Service

5285 Port Royal Road

Springfield, VA 22161

Telephone: (800) 553-6847

Facsimile: (703) 605-6900

E-mail: orders@ntis.fedworld.gov

Online ordering: http://www.ntis.gov/ordering.htm

OR

Lawrence Livermore National Laboratory

Technical Information Department's Digital Library

http://www.llnl.gov/tid/Library.html 
Interim Management Plan for the NIF Cryogenic Target Systems

Concur:

NNSA Assistant Deputy Administrator

for Research, Development, and Simulation

Approve:

NIF Director 


\section{Table of Contents}

1.0 INTRODUCTION.......................................................................

2.0 PRIMARY DESIGN CRITERIA AND FUNCTIONAL REQUIREMENTS .............. 2

3.0 ORGANIZATIONAL STRUCTURE............................................... 4

3.1 NIF Cryogenic Target Systems Program Manager...........................................................................................5

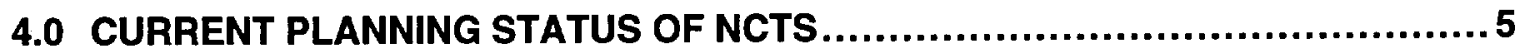

4.1 Program Baseline Schedule

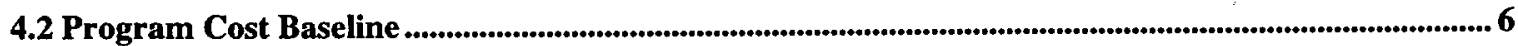

4.3 Estimate Cost and Timeline



5.1 Reporting to the NIF Director and NNSA by the Program Manager ........................................................6 6

5.2 Special reports and reviews of the NCTS Program........................................................................................6 6

ATTACHMENT 1 DRAFT NCTS PROGRAM EXECUTION PLAN.....................A1 


\subsection{Introduction}

Restricted availability of funding has had an adverse impact, unforeseen at the time of the original decision to projectize the National Ignition Facility (NIF) Cryogenic Target Handling Systems (NCTS) Program, on the planning and initiation of these efforts. The purpose of this document is to provide an interim project management plan describing the organizational structure and management processes currently in place for NCTS. Preparation of a Program Execution Plan (PEP) for NCTS has been initiated, and a current draft is provided as Attachment 1 to this document.

The National Ignition Facility is a multi-megajoule laser facility being constructed at Lawrence Livermore National Laboratory (LLNL) by the National Nuclear Security Administration (NNSA) in the Department of Energy (DOE). Its primary mission is to sup = -.. port the Stockpile Stewardship Program (SSP) by performing experiments studying weapons physics, including fusion ignition. NIF also supports the missions of weapons effects, inertial fusion energy, and basic science in high-energy-density physics. NIF will be operated by LLNL under contract to the University of California (UC) as a national user facility. NIF is a low-hazard, radiological facility, and its operation will meet all applicable federal, state, and local Environmental Safety \& Health (ES\&H) requirements.

The NCTS Interim Management Plan provides a summary of primary design criteria and functional requirements, current organizational structure, tracking and reporting procedures, and current planning estimates of project scope, cost, and schedule. The NIF Director controls the NIF Cryogenic Target Systems Interim Management Plan.

Overall scope content and execution schedules for the High Energy Density Physics Campaign (SSP Campaign 10) are currently undergoing rebaselining and will be brought into alignment with resources expected to be available throughout the NNSA Future Years National Security Plan (FYNSP). The revised schedule for delivering this system will be decided at the national level, based on experiment campaign requirement dates that will be derived through this process. The current milestone date for achieving indirect-drive ignition on the NIF is December 2010. Maintaining this milestone requires that the cryogenic systems be complete and available for fielding experiments early enough that the planned experimental campaigns leading up to ignition can be carried out. The capability of performing non-ignition cryogenic experiments is currently required by March 2006, when the NIF's first cluster of beams is operational. Plans for cryogenic and non-cryogenic experiments on the NIF are contained in NNSA's Campaign 10 Program Plans for Ignition (MTE 10.1) and High Energy Density Sciences (MTE 10.2).

As described in this document, the NCTS Program Manager is responsible for managing NIF Cryogenic Target Systems development, engineering, and deployment. Through the NIF Director, the NCTS Program Manager will put in place an appropriate Program Execution Plan (draft attached) at a later time consistent with the maturing and funding of these efforts. The PEP will describe management methods for carrying out these activities. 


\subsection{Primary Design Criteria and Functional Requirements}

The mission for the NCTS Program is to provide the equipment and procedures to fill, deliver, support, and characterize cryogenic targets for the NIF for indirect and directdrive ignition experiments and for non-ignition experiments. The Program will provide capability to perform experiments with targets requiring sub-ambient temperatures down to the cryogenic range of approximately 10 Kelvins.

The Primary Design Criteria and Functional Requirements establish the technical baseline for the NCTS. The Primary Design Criteria and Functional Requirements are approved by the NIF Director and NNSA.

The NCTS Primary Design Criteria are the highest-level capabilities that the NCTS must meet to satisfy its mission need and have been determined in consultation with and input from the experimental user communities and the NIF Project staff. The Functional Requirements flow down from the Primary Design Criteria and include other functional requirements either mandated from pre-existing constraints or resulting from stakeholder input. The proposed Primary Design Criteria and resulting NCTS Functional Requirements are summarized in Table 1. Details can be found in Appendix A of Attachment 1.

Table 1. Summary of NCTS Primary Criteria and Functional Requirements

\begin{tabular}{|c|c|}
\hline Category & Primary Criteria \\
\hline Target Types & $\begin{array}{l}\text { - Non-implosion targets without fuel capsules } \\
\text { - } \text { Equation of state targets } \\
\text { - } \text { Planar instability } \\
\text { - } \text { High-density-gas X-ray converters } \\
\text { - } \quad \text { Gas-filled hohlraums for hohlraum energetics or drive sym- } \\
\text { - metry } \\
\text { - X-ray drive and direct drive pre-ignition implosions } \\
\text { - D } \text { DT filled } \\
\text { - X-ray drive and direct-drive D-T filled ignition targets } \\
\text { - Targets with ignition and yield for "uses of ignition" ex- } \\
\text { periments }\end{array}$ \\
\hline Category & Functional Requirements \\
\hline $\begin{array}{l}\text { Target characterization at } \\
\text { shot time }\end{array}$ & $\begin{array}{l}\text { All target parameters that must be set and controlled by the } \\
\text { NCTS must be measured, recorded, and known at shot time }\end{array}$ \\
\hline Tritium inventories & $\begin{array}{l}\text { Up to } 50 \mathrm{Ci} / \text { target; } 75 \mathrm{Ci} \text { total in targets stored at NIF; } 500 \mathrm{Ci} \\
\text { facility limit (total tritium) }\end{array}$ \\
\hline
\end{tabular}




\begin{tabular}{|c|c|}
\hline NIF compatibility & $\begin{array}{l}\text { - Target Positioner System and positioning requirements } \\
\text { - } \text { Diagnostic configuration } \\
\text { - "Stay-Out" zones } \\
\text { - Chamber damage limits } \\
\text { - Controls and data logging } \\
\text { - Grounding and shielding } \\
\text { - Target Chamber Vacuum System }\end{array}$ \\
\hline Maximum shot frequency & $\begin{array}{l}\text { - Implosion shots: Every } 6 \text { hours } \\
\text { - Non-ignition shots: Every } 4 \text { hours }\end{array}$ \\
\hline $\begin{array}{l}\text { Maximum cryogenic implo- } \\
\text { sion targets filled and shot } \\
\text { in one week }\end{array}$ & $\begin{array}{l}\text { Pre-ignition: } 18 \text { during cryogenic target implosion campaign } \\
\text { weeks } \\
\text { - Post ignition yield shots: } 1 \text { per week }\end{array}$ \\
\hline $\begin{array}{l}\text { Maximum campaign week } \\
\text { frequency }\end{array}$ & $\begin{array}{l}\text { - Pre-ignition implosion campaigns: every other week } \\
\text { - Post ignition full yield: every week } \\
\text { - Non-ignition: continuous }\end{array}$ \\
\hline $\begin{array}{l}\text { Reliability, availability, and } \\
\text { maintainability }\end{array}$ & $\begin{array}{l}\text { Designs and system configuration should strive to provide a } \\
\text { system capable of meeting the NIF experiment schedule with a } \\
\text { reliability of } 95 \%\end{array}$ \\
\hline Design standards & $\begin{array}{l}\text { LLNL accepted and applicable codes, standards, and guides } \\
\text { should be utilized whenever available }\end{array}$ \\
\hline $\begin{array}{l}\text { Safety and regulatory re- } \\
\text { quirements }\end{array}$ & $\begin{array}{l}\text { - Comply with applicable federal, state, and regional safety } \\
\text { regulations (e.g., DOT, NRC, OSHA) and DOE orders } \\
\text { - Comply with limits and requirements for NIF operations } \\
\text { (e.g., OSRs, FSAR and OSPs) (NIF hazards category is low } \\
\text { hazard, radiological) } \\
\text { - Comply with NIF radiological dose limits of } 500 \mathrm{mrem} / \mathrm{yr} \\
\text { per worker, } 10 \text { person-rem/yr total, and } 0.2 \text { person-rem } / \mathrm{y} \\
\text { for the public ( } 82 \mathrm{Km} \text { )b } \\
\text { - Implement Integrated Safety Management }\end{array}$ \\
\hline Environmental Protection & $\begin{array}{l}\text { Meet NIF environmental permit requirements } \\
\text { - Air discharge limited to } 30 \mathrm{Ci} / \mathrm{yr} \\
\text { - Water discharge limited to } 1 \mathrm{mCi} / \text { day } \\
\text { Follow applicable guides and standards }\end{array}$ \\
\hline $\begin{array}{l}\text { Decontamination, decom- } \\
\text { missioning, and disposal }\end{array}$ & $\begin{array}{l}\text { Design of equipment will consider future decontamination and } \\
\text { decommissioning needs (e.g., non-activating materials, etc.) }\end{array}$ \\
\hline Quality Assurance & $\begin{array}{l}\text { Meet the requirements of DOE Order 414.1, Quality Assurance } \\
\text { and 10CFR } 830 \text { Subpart A, Quality Assurance Requirements. }\end{array}$ \\
\hline
\end{tabular}




\subsection{Organizational Structure}

This section defines the interim structure for managing this Program. More complete detail on the roles and responsibilities of these individuals pertaining to NIF facilitization and their interface with other responsible entities are described in detail in Attachment 1. Here, we provide descriptions that pertain only to the management of the Program and do not necessarily include all of the responsibilities associated with each position.

The cryogenic target systems are equipment and capabilities identified as essential for NIF to successfully accomplish its experimental missions. The NCTS activities that provide these equipment and capabilities are significant and require several years for completion. The NCTS is the responsibility of the NIF Director and is funded as part of Campaign 10 of the Stockpile Stewardship Program of the National Nuclear Security Administration (NNSA). It is envisioned that as the Program reaches maturity, it have welldefined technical, cost, and schedule baselines, which will be managed using documented change control procedures. A preliminary version of the management model expected to be put in place for this program once it reaches maturity is included in Attachment 1.

As shown in Figure 3-1, the management of the Program follows the lines of responsibility from NNSA through the NIF Director to the individual elements within the Program. These elements are anticipated to be national in nature, with activities at multiple laboratories, possibly including laboratories outside of the stockpile stewardship communities. In particular, the NCTS major participants include LLNL, Los Alamos National Laboratory (LANL), and General Atomics, with strong technical input from the University of Rochester Laboratory for Laser Energetics as well as Centre d'Etudes Atomique in France.



Figure 3-1. NCTS Management organization chart 


\subsection{NIF Cryogenic Target Systems Program Manager}

The NIF Cryogenic Target Systems Program Manager (the "Program Manager") is responsible for the planning, prioritization, budgeting, and reporting of this program. The Program Manager reports to the NIF Director and is responsible for:

- Developing and maintaining the Primary Design Criteria and Functional Requirements for the deliverables that are approved by the NIF Director and NNSA.

- Developing a set of System Design Requirements that flow down from the Primary Criteria and Functional Requirements that are maintained under configuration control.

- Developing and maintaining a budget and schedule for the program of work consistent with the NIF experiments schedule and available funding from NNSA.

- Establishing working agreements, with the participating laboratories including formal memoranda of understanding and Control Account Plans (CAPs) that will cover scope of work, funding, and deliverables.

- Establishing detailed yearly work plans through CAP Reporting and reviewing status on progress of work.

- Establishing and heading a program management structure to execute the work.

- Developing and implementing NCTS Program Risk Management Plans. This will include developing ES\&H Risk Management and Quality Assurance Plans Identifying those subsystems whose failure could result in radiation exposure to workers, the public, or the environment, and are therefore under the requirements of $10 \mathrm{CFR}$ 830.120 subpart $\mathrm{A}$ and obtaining all required concurrences on their quality level designation.

\subsection{Current Planning Status of NCTS}

\subsection{Program Baseline Schedule}

The NCTS Program is accomplished in several phases: Conceptual Design, Preliminary Design, Final Design, Procurement of First Items, Test and Modify, Final Procurement and Verification, Title III Engineering/Operations Documents, and Hand-off. Each of the several subsystems of the NCTS will have its own detailed schedule, which must be coordinated to provide subsystems for integration tests at the proper time. At the current time, the NCTS Program is in Pre-Conceptual Design phase.

The Program Integrated Schedule is also driven by two major Inertial Confinement Fusion (ICF) Milestones: start of non-ignition cryogenic experiments and start of cryogenic ignition experiments. These are Level 1 NCTS milestones. Overall scope, content, and execution schedules for the High Energy Density Physics Campaign (SSP Campaign 10) are currently undergoing rebaselining and will be brought into alignment with resources expected to be available throughout the NNSA FYNSP. It is anticipated that these activities/milestones are likely to be impacted by this process. The ability of the NCTS Program to meet these milestones and complete its currently envisioned schedule of work will depend on yearly funding levels. These funding levels have not yet been finalized, and therefore the NCTS Integrated Schedule should be considered provisional. The inte- 
grated schedule shown in the draft PEP in Appendix A is based on pre-conceptual design information, and will be updated during conceptual design and further refined during preliminary and final design. This schedule also does not include out-year funding constraints from NNSA.

\subsection{Program Cost Baseline}

The profile of funding and costs for the NCTS program has not yet been established and agreed to by the Director of the Office of Secondaries and Inertial Fusion and the NIF Director. A needs-based pre-CDR estimate of costs and cost profile was developed by members of the NCTS Program and modified to take into consideration a realistic manpower plan. The pre-conceptual level cost profile is consistent with the pre-CDR provisional Integrated Schedule. It will be updated during conceptual design and further refined during preliminary and final design.

\subsection{Estimate Cost and Timeline}

Preliminary cost and schedule estimates for the system described in the document NIF Cryogenic Target Systems Pre-CDR Description (currently in preparation) shows a total estimated cost of $\$ 124 \mathrm{M}$ and completion of an indirect-drive capability in FY08 and a direct-drive capability in FY13. The cost estimates based on pre-conceptual design information will be updated when conceptual design is complete and will be further refined during preliminary design. The schedule is consistent with the funding profile and assumes that funds will be available at the specified levels for the period FY 2002-2008.

\subsection{Reporting and Reviews}

The NCTS Program will track and report status and progress and identify and correct problems through a hierarchy of reporting processes.

\subsection{Reporting to the NIF Director and NNSA by the Program Manager}

The NCTS Program Manager will compile semi-annual status reports with input from all of the subsystem leaders. The reports will contain narrative information on progress and issues along with schedule and cost status. Risk concerns will be addressed along with proposed plans for risk control monitoring/mitigation/ corrective action. This report will be sent to the NIF Director by the 20 th working day after the end of the reporting period.

\subsection{Special reports and reviews of the NCTS Program}

At the appropriate time and if justified by the level of funding, the NCTS Program will prepare the following formal reports:

- Requirements Document comprising the Primary Criteria, Functional Requirements, Subsystem Design Requirements, and Subsystem Interface Definitions. These will be reviewed and approved at a Pre-CDR NCTS Concept review (see next bullet). 
- Pre-CDR NCTS Concept report, which will be completed by updating and completing the document, NIF Cryogenic Target Systems Pre-CDR Description (the NCTS Pre-CDR Description is currently in preparation). A review of this pre-CDR concept will be conducted for all stakeholders. The review will include a discussion of the options considered for meeting the requirements. This will establish the baseline concept that will be carried forward into the Conceptual Design Phase.

- Program Execution Plan

- Quality Assurance Program Plan

- Risk Management Plan

- Safety Basis documents

- Conceptual Design Report. A review of the Conceptual Design will also be conducted for all stakeholders as part of the approval process required for proceeding forward with this program.

- Formal reports of reviews that will be held at the completion of preliminary and final designs and at the completion of integrated testing prior to system commissioning. 


\section{Attachment 1: Draft NCTS Program Execution Plan}

